\title{
Petroleum Engineering as a (still) Promising Career in Geosciences? An Empirical Example in Northeastern Mexico
}

\author{
Elizabeth Chacon B. ${ }^{1, *}$, Jorge A. Briones Carrillo ${ }^{1}$, Carlos G. Aguilar-Madera ${ }^{1}$, Nelson E. \\ Barros-Galvis ${ }^{1}$, Sóstenes Méndez-Delgado ${ }^{1}$ \\ ${ }^{1}$ Universidad Autónoma de Nuevo León, Facultad de Ciencias de la Tierra, Carretera a Cerro \\ Prieto Km. 8, Linares, Nuevo León, México 67700, México \\ *Correspondence: Universidad Autónoma de Nuevo León, Facultad de Ciencias de la Tierra, \\ Carretera a Cerro Prieto Km. 8, Linares, Nuevo León, México 67700, México
}

Received: February 28, 2017 Accepted: July 27, 2017 Published: December 13, 2017

doi:10.5296/ije.v9i4.12297 URL: https://doi.org/10.5296/ije.v9i4.12297

\begin{abstract}
More than ever, it is the time to increase the number of engineering students applying to geosciences in order to satisfy the growing national challenges and administrate our natural resources in a responsible and sustainable manner. This work analyzes the petroleum engineer career at the UANL through an 8-yr experience in order to critically evaluate the current academic profile that Petroleum Engineers need within a global and shared world. This brief appraisal also presents an updated revision of all certified academic programs offering the Petroleum Engineering career in Mexico. At the same time, this work also proposes a modest but realistic academic modality for this particular career to better fulfill the actual academic and industrial demands on this area. Adjusting the academic geoscience workforce implies a redefinition of curricular programs, values and competences for this career in a synergic action with government policies and public and private employees worldwide. Certainly, the change should be the driving force to design modern up-to-date professional profiles and better oil professionals with a global perspective to take on alternative development.
\end{abstract}

Keywords: Petroleum Engineering, Oil industry, geosciences career, academic profiles 


\section{Pursuing a Career in the Oil and Gas Industry}

A time comes in life when students face perhaps their most important choice: to pursue a university career, and to make a living of it. Different extrinsic and intrinsic factors play a role: a family tradition if some members are inside the petroleum industry, an economical convenience, the friends' influence, local familiarity, a long lasting aspiration or even pure and banal greed. Nowadays, a profession related to Energy and Geosciences is probing to be a smart choice among bachelor candidates. They have a strong desire to succeed, with higher financial expectations as others geo-peers. Since several years now the geoscience workforce in the oil and gas industry in Mexico is crossing a generational transition, a general situation that has been accentuated due to the recent Energetic Reform approved in 2013 (Gobernación, 2013). The need for young trained personnel as Petroleum Engineering (hereafter PE) agglutinated recent graduates from the whole nation for preparation courses, a widespread practice everywhere around the world (LaDue N.D. \& Manning, 2015). The aim of this work is to share the experience derived from the Earth Science Faculty (hereafter FCT) at the Autonomous University of Nuevo Leon (UANL), as an example of a rapid growing career offered in Mexico within this changing and demanding work industry.

The FCT at UANL is located at Linares near to Monterrey, which is the main city in northeastern Mexico. In general, there is limited transportation, an extreme weather (from 0 to $5^{\circ} \mathrm{C}$ in winter and up to $45^{\circ} \mathrm{C}$ in summer) and an unbalanced diet for most of the academic year. Although infrastructure is basic and some laboratories are still under development, the FCT is continuously growing (Figure. 1). Natural and social resistance is also well-practiced here, for they intermix with different cultural values, heritage and attitudes, not to mention the backgrounds' diversity and peculiar personalities among teachers. Nonetheless, these very limitations may be acting as a positive selection pressure to force students to turn into more creative people with higher adaptation abilities. From all careers offered at the FCT, PE students outstand by their responsibility, their higher quality in homework and class presentations, their image caring and social involvement with theirs peers. In contrast, geologists, geophysics and mineralogists are more capable and adaptable in field activities.

In addition to other technical qualifications, a PE must exhibit a natural ability to construct and enjoy working outdoors as a team or individually, and a strong emotional intelligence to endure physical and social temporal isolation. Among the four careers offered, Petroleum students are the most resilient to continue the university career. Over the years, the observed trend is that from the total enrolled and matriculated students among PE, men tend to be more persistence, efficient and hired in the industry. Then again, women have any other valid reasons to stop or continue their careers, being marriage and maternity the most typical defining situations. From the few remaining competitive women in this area, they are usually good-paid minority workers. In fact, from the habilitation perspective, the college atmosphere at FCT may be rather an asset: extreme weather and limited comfort in a city with few cultural offers, sports and commodities surely paves the adaptation process toward their future professional life. For instance, to get to the Faculty, there are only a few buses per day, and that means that any student is out of town for most of the day. Far from glamorous, the "night-life" is confined to their peers and reunions as often as they want or can. This 
acclimatization to physical and social harsh conditions actually promotes a kind of Darwinian fitness. Because they learn to be socially limited, they develop a greater accountability on teamwork. Holidays and weekends are normally taken to get home even for a few days, so they also show a relative higher mobility.

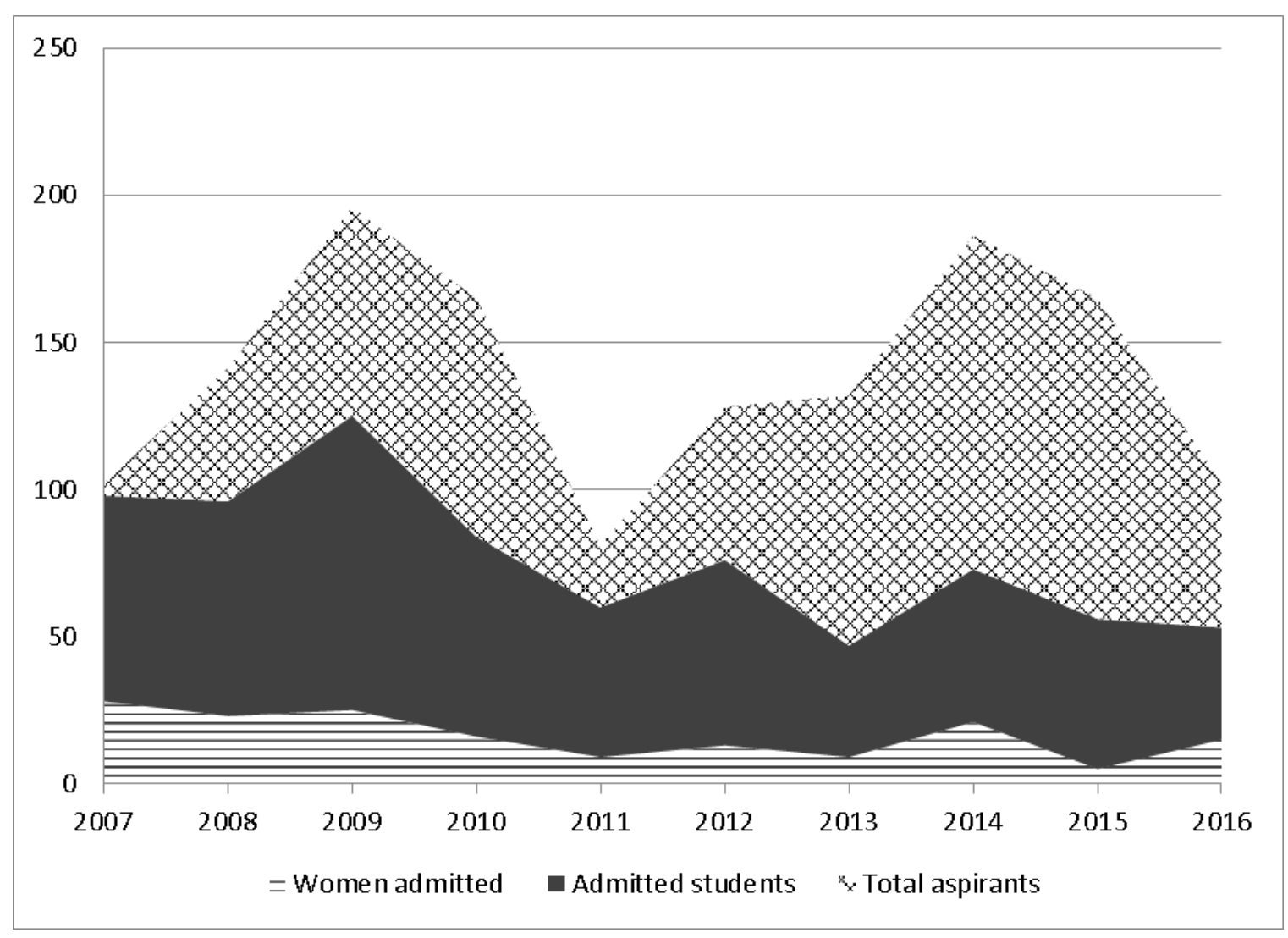

Figure 1. Yearly Averages from the Petroleum Engineering career at Earth Science Faculty (FCT)

\section{Outcomes from the Youngest Career at the FCT, UANL}

The PE education at FCT is relatively a brand new career at UANL, while the other careers (Geological, Geophysical and Geological-Mineralogist) are more than 30-yr-old. The PE program opened in August 2007 as a response to the educational demand for industry. At that time, most of the students came from foreign States around Nuevo Leon, many from petroleum-rich states such as Veracruz, Tabasco, and Campeche. Since the first year, applicants were accepted after a general exam, averaging only $70 \%$ of the total. After five generations and a reasonable insertion labor in the industry, the FCT continues matriculating around 60 students per year only within this program. At present, there are many universities listing a PE instruction, amounting approximately 33 schools mainly concentrated around the Gulf of Mexico (ANUIES, 2016), a distribution that correlates well with the Tampico-Misantla, Burgos, and Veracruz oil basins (Figure. 2). There is a clear substantial 
offer with a less than 10-yr-old PE program in these states.

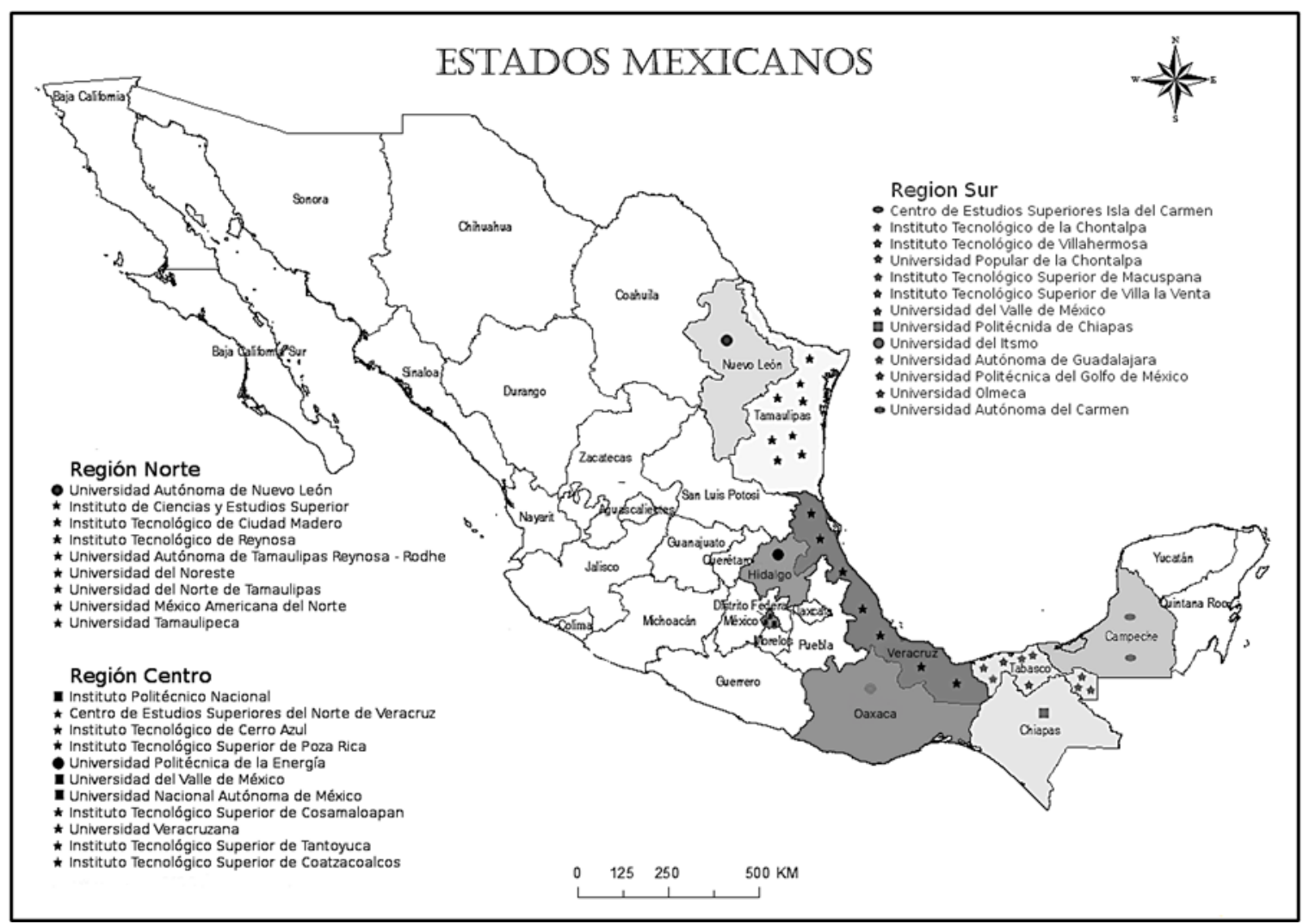

Figure 2. List of officially acknowledged Mexican Universities and Institutes with a Petroleum Engineering catalogue (according to the Mexican Secretariat of Public Education, SEP).

As in most universities, the lack of full time professors for PE students is one main issue. To face this problem, industry-experienced teachers are invited by short periods per semester for intensive 1-2 weeks courses with practical field experiences. Most visiting professors have come from the Instituto Politécnico Nacional (IPN), and Petróleos Mexicanos (PEMEX, 2012), and during the last six years even oil engineers from Venezuela and Colombia. All other academic units are taught by full-time lecturers on a regular basis.

On the other hand, most students request a greater flexibility to choose among more specific subjects, but they mainly ask for a direct contact with oil fields and facilities, just as in the USA (Cramer, 2015), where most universities offering field-camp experience has been markedly low since 1995 (Petrovic, 2014). As in the majority of Mexican Universities, the lack of modern laboratory infrastructure in our institution is a major limitation probable related to the number or accepted students.

The required synchronization among national demands, industry and scholar programs already advanced learning and teaching strategies nationwide during the past decade. Human resources training, creation and improvement of existing university infrastructure have been oriented from the Mexican Government toward strategic demands as those related to energy 
(Secretariat of Energy, 2014). In fact, the productive National Oil Company, PEMEX, has identified the top priority challenges for the next 10 years (PEMEX, 2012), offering valuables guidelines for Universities and Research Centers to train students for scientific and technological research. Such formal scholastic reforms and upgrades are supposed to render better teaching-learning results, but though the education model at UANL allows modifications and updates at least every 5-year, their implementation is still moderately effective since the teachers/alumni ratio is low. However it is easier to get a career related to Energy Engineering nowadays with far better opportunities and flexibility than a few years ago.

Frankly, a career in the seductive oil world outstands for their high economic and organizational standards, which is to be expected from an industry that historically has empowered the national economy worldwide. Taking aside any moral prejudice or ethical argument, the reasons as to why young students find attractive this profession may be the same valid reasons as seven decades ago. Except perhaps for the fact than at that time, people took a greater pride for a pioneer work in building a city and industrializing the society (Meehan, 2015), unlike to the overexploited today's world.

\section{Developing a PE Profile for our 21st Century}

The actual study plan is based on geological, physics, geophysics, chemical and mathematics frameworks. Three identified areas are drilling, reservoir and production engineering (Figure. 3A) under our local and current conditions. The Hydrocarbon Engineering (hereafter HyE) program here proposed (Figure. 3B) is nested within a humanitarian, technical and economical multidisciplinary perspective. The target is to develop an integral leader that can solve problems with social responsibility in Geosciences, where environmental consciousness is an implicit trait. The multidisciplinary core of any study program should enclose climate, environment and sustainability among the most challenging issues to cope with.

Although basic aspects wait to be fulfilled by schools and by other public and private instances, geosciences experts are on demand around the world. Everywhere the enrollment for geosciences bachelor studies is increasing, even when professional training opportunities for graduates and undergraduates are relatively stagnant or even contracted (INEGI, 2016). Many universities receive more applicants for graduate programs in Geosciences each semester, and yet, the number of funded available positions for graduate student is limited, which might be indicative of an important area still to develop.

As recognized by the oil and gas industry and according to national needs, a PE should be proficient in exploration and exploitation of shale, carbonates, turbidites and deep-water reservoirs, including new enhanced oil-recovery techniques. A further and honest scrutiny may even acknowledge that probably a single Faculty program may be unable to provide an integral profile for PE. A sounder and viable alternative would be if each school could focus on just one area, depending on its proved competences and expertise, for upbringing better prepared-specialists; in the case of FCT, a PE especially skilled for exploration with a strong geological background. 


\section{Macrothink}

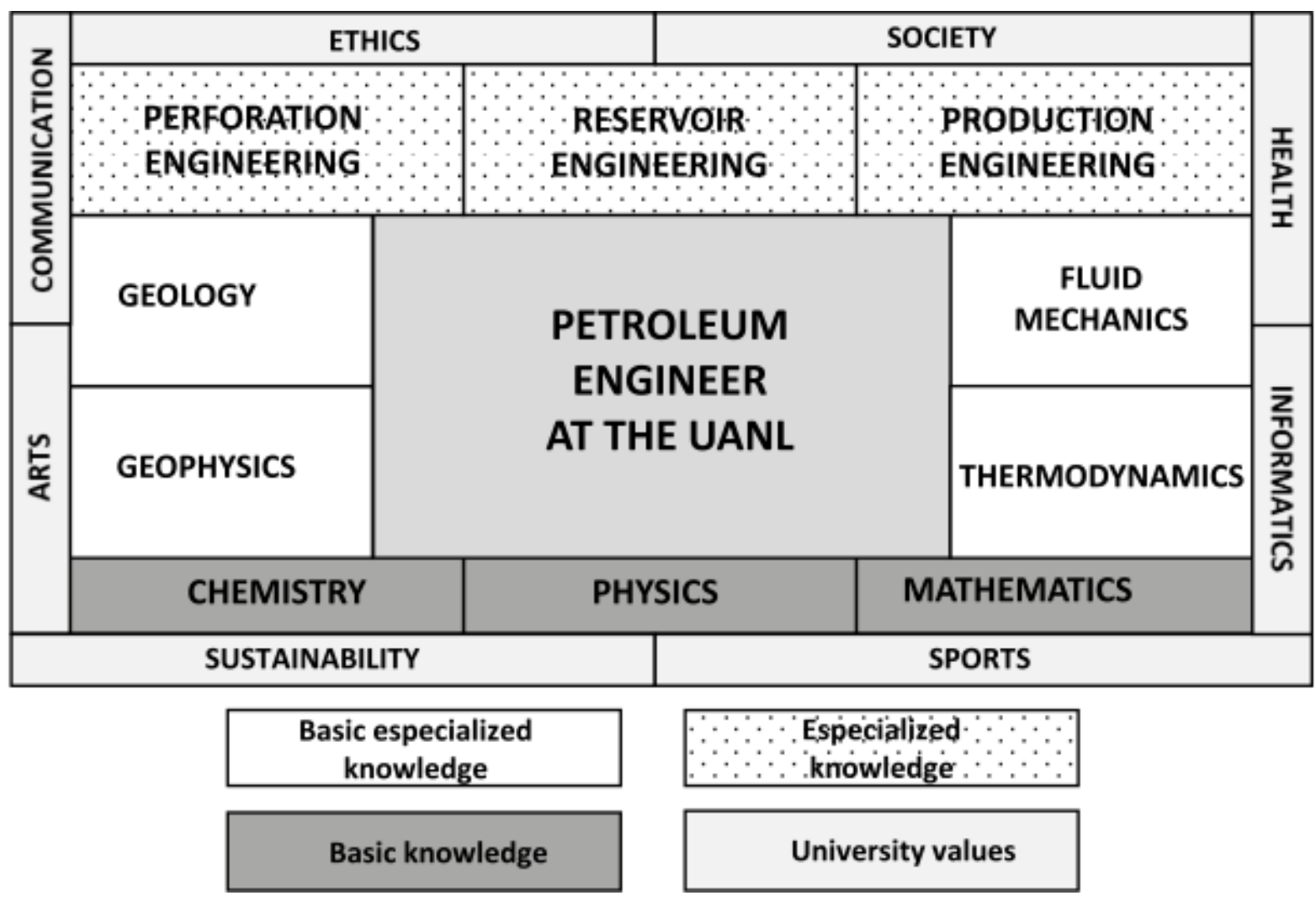

Figure 3A. Current Curricular Program for Petroleum Engineering at FCT-UANL

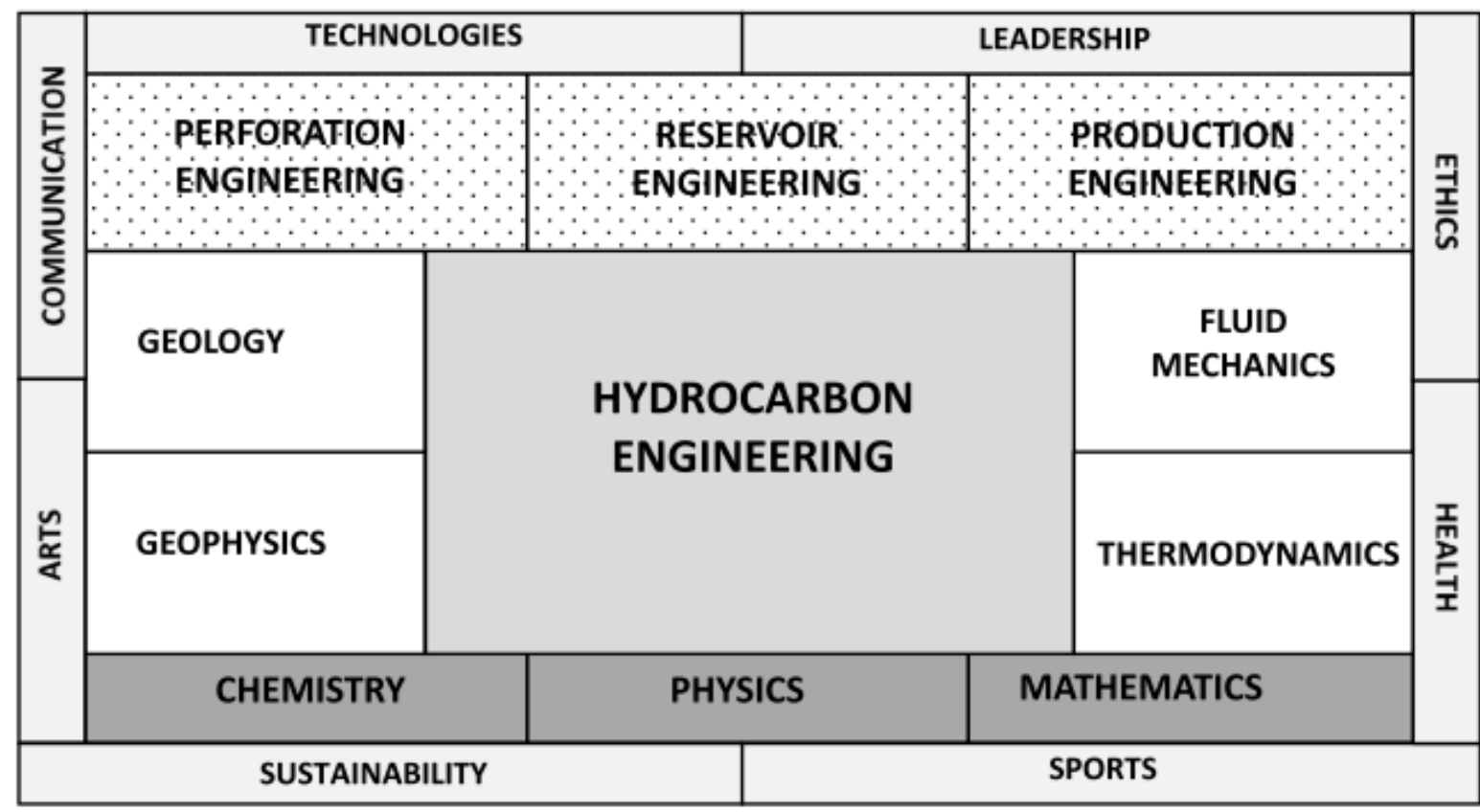

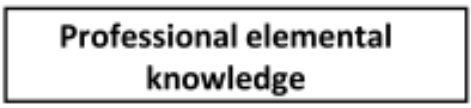

Elemental knowledge

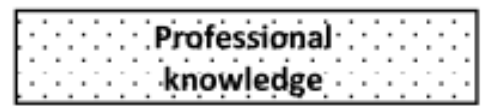

Complementary

Figure 3B. Proposed curricular program for Hydrocarbon Engineering 


\section{Conclusions}

Young are motivated by several factors, being a financial, scholastic and social hierarchical status the most common goal. Since their university ingress, students are already fully engaged in seeking field and industrial opportunities to specialize in any of the three main pathways of oil and gas engineering: exploration, production, exploitation, namely, downstream in the industry. The fact that students identify themselves as specialists, instead of geoscientists and petroleum engineers, reflects their increasingly narrow focus of study. In spite of the probably temporal, petroleum industry crisis these days and the paucity of energies derived from non-renewable resources, the proposed instruction as HyE may cover this gap by developing alternative energy sources. Evidently, modern industry needs better infrastructure and equipment to explore and advance deep water, mature reservoirs, unconventional resources, and refined stimulation-production processes. On the other hand, the global demand for geoscientists continues to grow (Martinsen et al., 2012).

We need to prepare engineers ready to produce, exploit and distribute energy, daring people who are not afraid to introduce environmentally-friendly practices and make good profit of it at every level. The future generation of geoscientists rest upon the actual undergraduate community and their ability to prepare to be successful in the workforce (Summa et al, 2017). Yet, beyond the current professional skills, a PE needs a genuine social and environmental commitment toward a sustainable world. But this new way of thinking and doing requires that resources and needs parallels with satisfactory solutions and qualifications to be formally inserted into a career design. If academia is going to succeed in producing high-level professionals able to fulfill legitimate society demands, this is the time to switch our and their mental frame to provide better educational competences in geosciences.

\section{Acknowledgements}

Authors are very thankful to Dr. Ignacio Navarro de León for his suggestions and to the anonymous reviewers for their insightful comments, and to Editors for their professional guidance through this process.

\section{References}

ANUIES. (2016). Asociación Nacional de Universidades e Instituciones de Educación Superior. Recuperado el 31 de July de 2016, de http://www.anuies.mx

Cramer B., K. L. (12 de 2015). Who build the 21 century? GSA Today, 25.

Gobernación, S. d. (2013). Official Journal of the Federation. Diario Oficial de la Federación, DCCXXIII, págs. 2-13.

INEGI. (2016). http://www3.inegi.org.mx. (M. Instituto Nacional de Estadística y Geografía, Editor) 


\section{Macrothink}

International Journal of Education ISSN 1948-5476 2017, Vol. 9, No. 4

LaDue N.D., \& Manning, C. (2015). Next generation Science Standards: A call to action for the geoscience community. GSA Today, 25(2), 28-29. https://doi.org/10.1130/GSATG233GW.1

Martinsen, O.J., Talwani, M., Levander, R, Dengo, C., Barkhouse, B., Dunn, J.F., Link, C., Mosher, S., Tatham, R., Orcutt, J., Paul, D., \& Talley, R. (2012). A U.S. human resource challenge for Earth science education and energy exploration and exploitation: The Leading Edge, $30^{\text {th }}$, Anniversary Volume, v. 31, 714-716 p.

Meehan, N. (2015). Improving People's Lives: What You Do is Important. JPT, 67(10), 14-16. https://doi.org/10.2118/1015-0014-JPT

PEMEX. (2012). Programa estratégico tecnológico. Petróleos Mexicanos, Petróleos Mexicanos y Organismos Subsidiarios. 2013-2027.

Petrovic, H. S. (24 de 7 de 2014). Geoscientists' perceptions of the value of undergraduate field education. GSA Today, 24(7), 4-10. https://doi.org/10.1130/GSATG196A.1

Secretariat of Energy. (2014). Programa estratégico de formación de recursos humanos en materia energética. México.

Summa, L., Keane, C., \& Mosher, S. (2017), Meeting Changing Workforce Needs in Geoscience with New Thinking about Undergraduate Education. GSA Today, 27(9), 60-61. https://doi.org/10.1130/GSATG342GW.1

\section{Glossary}

ANUIES: Asociación Nacional de Universidades e Instituciones de Educación Superior, México

FCT: Facultad de Ciencias de la Tierra (Earth Science Faculty)

HyE: Hydrocarbon Engineering

INEGI: Instituto Nacional de Estadística, Geografía e Informática

IPN: Instituto Politécnico Nacional

PE: Petrleum Engineering

PEMEX: Petróleos Mexicanos

SEP: Secretaria de Educación Pública (México)

UANL: Universidad Autónoma de Nuevo León (Autonomous University of Nuevo Leon) 


\section{Copyright Disclaimer}

Copyright for this article is retained by the author(s), with first publication rights granted to the journal.

This is an open-access article distributed under the terms and conditions of the Creative Commons Attribution license (http://creativecommons.org/licenses/by/3.0/). 